\title{
Volwaardige coassistentschappen kunnen al in het derde studiejaar beginnen $^{1}$
}

\author{
E.W.M.T. ter Braak • H.G. Gooszen
}

Vroege kennismaking met de praktijk maakt inmiddels in één of andere vorm deel uit van vrijwel alle geneeskundecurricula in Nederland. Het Utrechtse curriculum (CRU'99) is met twee volwaardige coschappen in het derde studiejaar nog een stap verder gegaan. De keuze viel op interne geneeskunde en chirurgie vanwege het beoogde algemene medische karakter binnen een klinische setting. Gedurende twee maal zes weken participeert de student zoveel als mogelijk in het gewone werk op de afdelingen: de ondernomen (leer)activiteiten zijn authentiek, dat wil zeggen direct afgeleid van het latere beroep van arts. De coassistent spreekt en onderzoekt zelfstandig patiënten en legt een professionele relatie met hen.

In een systematische review wordt onderbouwd dat vroege klinische ervaring meerwaarde heeft en dat de opleiding daarmee beter aansluit bij de maatschappelijke behoeften. ${ }^{1}$ Het gekozen beroep komt vroeg in de opleiding tot leven en de student ervaart het belang en de relevantie van theoretische kennis 'aan den lijve'. Dit verhoogt de motivatie en bevordert het rendement doordat theoretische kennis beter beklijft. ${ }^{2}$ Vroege coschappen dragen bij aan de persoonlijke en professionele ontwikkeling van toekomstige artsen: het vermogen om empathische arts-patiëntrelaties aan te gaan en het inzicht in ethische en maatschappelijke aspecten nemen toe. ${ }^{2}$ Doordat tijd wordt ingeroosterd voor contextgerelateerde studie krijgt de arts in spe de juiste attituden voor 'een leven lang leren' als het ware met de paplepel

E.W.M.T. ter Braak $(\bowtie)$

Mw. prof. dr. E.W.M.T. ter Braak is internist, UMC Utrecht. Correspondentieadres:Mw. prof. dr. E.W.M.T. ter Braak,

UMC Utrecht, Interne Geneeskunde, Heidelberglaan 100,

3584 CX Utrecht;email: e.terbraak@umcutrecht.nl.

Belangenconflict: geen gemeld.Financiële ondersteuning: geen gemeld. ingegeven. ${ }^{3}$ De groepsbijeenkomsten in afwisseling met werkzaamheden op de afdeling dragen bij aan een veilige leeromgeving. Formatieve beoordeling heeft een krachtig effect binnen het coschap zelf, maar ook ten opzichte van latere coschappen en andere studieonderdelen. Ook maakt een beoordeling vroeg in de opleiding duidelijk voor welke enkeling een andere beroepskeuze geschikter is.

Waar studenten gewoonlijk in hun eigen wereld leven', zorgen vroege coschappen voor een authentieke en maatschappelijk realistische context voor hun biomedische kennis. Daarmee komen kennis en de moderne opvattingen over professionaliteit zo vroeg mogelijk in onderlinge samenhang over het voetlicht. ${ }^{4}$ Dat dit zijn vruchten afwerpt, blijkt ook uit onze ervaringen: wij zien studenten terug tijdens hun semi-artsstages in het zesde jaar en zij blijken in staat om professioneel te functioneren op het niveau van eerstejaarsartsen in opleiding tot specialist. ${ }^{1}$

\section{Summary}

The undergraduate medical curriculum in Utrecht provides students with early clinical experience in their third year by two full clinical placements in general medical areas. With this, an optimum context for the integration of biomedical knowledge is achieved. The doctor in training gains experience in an authentic setting as early as possible in the medical education programme with modern opinions on professionalism that fit in with current societal requirements. (Braak EWMT ter, Gooszen HG. Full clinical placements for medical students can start as early as the third year of training. Dutch Journal of Medical Education 2007;26(5): 247-248).

\footnotetext{
${ }^{1}$ Dit artikel verschijnt ook in het Nederlands Tijdschrift voor Geneeskunde.
} 


\section{Literatuur}

Littlewood S, Ypinazar V, Margolis SA, Scherpbier A, Spencer J, Dornan T. Early practical experience and the social responsiveness of clinical education: sytematic review. BMJ 2005;331:387-91.

Dahle LO, Brynhildsen J, Behrbohm Fallsberg M, Rundquist I, Hammar M. Pros and cons of vertical integration between clinical medicine and basic science within a problem-based undergraduate medical curriculum: examples and experiences from Linköping, Sweden. Med Teach 2002;24:280-5.

Shaughnessy AF, Slawson DC. Are we providing doctors with the training and tools for lifelong learning? BMJ 1999;319:1280-3.

Scavenius M, Schmidt S, Klazinga N. Genesis of the professionalpatient relationship in early practical experience: qualitative and quantitative study. Med Educ 2006;40:1037-44. 